\title{
Evaluation of Potential Geo-tourism Based on Geo-diversity Towards Sustainable Tourism at Citarum River
}

\author{
MOHAMMAD SAPARI DWI HADIAN ${ }^{1}$, BOMBOM RACHMAT SUGANDA ${ }^{2}$, \\ UTE LIES SITI KHADIJAH3, AYU KRISHNA YULIAWATI ${ }^{4}$ \\ ${ }^{1}$ Geological Engineering, UNIVERSITAS PADJAJARAN, INDONESIA. E-mail: sapari@unpad.ac.id \\ ${ }^{2}$ Geological Engineering, UNIVERSITAS PADJAJARAN, INDONESIA. \\ E-mail: bombom.rachmat.suganda@unpad.ac.id \\ ${ }^{3}$ Communication Science, UNIVERSITAS PADJAJARAN, INDONESIA. E-mail: ute.lies@unpad.ac.id \\ ${ }^{4}$ Management, UNIVERSITAS PENDIDIKAN INDONESIA, INDONESIA. E-mail: ayukrishna upi.edu
}

\begin{abstract}
The research aims to identify and map geodiversity as excellent potential for geo-heritage and geo-tourism attraction, also classify them into geo-tourism destination. Research used qualitative method with descriptive analysis, with data collection through desk study, field observation and analysis of geodiversity and getourism. The main result identified that there are 43 geo-diversity in the upper Citarum River with geo-heritage and potential geo-tourism. The research classified geo-sites into three geo-tourism destination, which are: primary geo-tourism destination, secondary and supporting tourism destination. The Citarum river is one of the main rivers in West Java, which has become a vital source of water and economic activities for West Java community. Citarum river area has geodiversity with a geo-heritage potential which are scattered throughout the region. Environmental degradation has occurred in the area, protection of geo-heritage is important for the geo-tourism. Citarum river area has a potential as the main geo-tourism destination in Bandung City. Therefore, conservation of geo-heritage requires a good planning and policies.
\end{abstract}

Keywords: Citarum River; Geodiversity; Geo-tourism; West Java.

JEL Classification: Q01, Z32, Z39

Received: June 08, 2021

Accepted: September 27, 2021 


\title{
Evaluación del Potencial Geoturístico basado en la Geodiversidad para un Turismo Sostenible en el Río Citarum
}

\author{
MOHAMMAD SAPARI DWI HADIAN ${ }^{1}$, BOMBOM RACHMAT SUGANDA ${ }^{2}$, \\ UTE LIES SITI KHADIJAH3, AYU KRISHNA YULIAWATI ${ }^{4}$ \\ ${ }^{1}$ Geological Engineering, UNIVERSITAS PADJAJARAN, INDONESIA. E-mail: sapari@unpad.ac.id \\ ${ }^{2}$ Geological Engineering, UNIVERSITAS PADJAJARAN, INDONESIA. \\ E-mail: bombom.rachmat.suganda@unpad.ac.id \\ ${ }^{3}$ Communication Science, UNIVERSITAS PADJAJARAN, INDONESIA. E-mail: ute.lies@unpad.ac.id \\ ${ }^{4}$ Management, UNIVERSITAS PENDIDIKAN INDONESIA, INDONESIA. E-mail: ayukrishna upi.edu
}

\begin{abstract}
RESUMEN
El objetivo de la investigación es identificar y cartografiar la geodiversidad como un excelente potencial para la atracción del geopatrimonio y el geoturismo, así como clasificarla como destino geoturístico. La investigación utilizó un método cualitativo con análisis descriptivo, con recogida de datos a través del estudio de gabinete, la observación sobre el terreno y el análisis de la geodiversidad y el geoturismo. El resultado principal identificó que hay 43 geodiversidades en el alto río Citarum con geopatrimonio y geoturismo potencial. La investigación clasificó los geositios en tres destinos geoturísticos, que son: destino geoturístico primario, secundario y de apoyo. El río Citarum es uno de los principales ríos de Java Occidental, que se ha convertido en una fuente vital de agua y actividades económicas para la comunidad de Java Occidental. La zona del río Citarum posee una geodiversidad con un potencial geopatrimonial que se encuentra dispersa por toda la región. En la zona se ha producido una degradación medioambiental, por lo que la protección del geopatrimonio es importante para el geoturismo. La zona del río Citarum tiene potencial como principal destino geoturístico de la ciudad de Bandung. Por lo tanto, la conservación del geopatrimonio requiere una buena planificación y políticas.
\end{abstract}

Palabras clave: Río Citarum; Geodiversidad; Geoturismo; Java Occidental.

Clasificación JEL: Q01, Z32, Z39

Recibido: 08 de Junio de 2021

Aceptadp: 27 de Septiembre de 2021 


\section{Introduction}

In the long-term thinking about natural resources, the main foundation is sustainable development in which human activities are carried out. (Mihic \& Andrejevic, 2012; Amir, Ghapar, Jamal, \& Ahmad, 2015; Arora, 2020). There is a holistic idea to take care, learn and develop the geological heritage as the main source for geo-tourism (Lazzari \& Aloia, 2014). To promote the development of sustainable tourism in areas around the world, the geo-tourism is used as a media (Zhang, Tian, Wu, \& Mei, 2013). Geotourism has become one of the main themes of sustainable tourism development (Pásková, Zelenka, Ogasawara, Zafala \& Astete, 2021).

Initially, geo-tourism was first described as tourists service and facilities to obtain the science and comprehension of the geology and geomorphology of a geosite (Hose, 1995; Wijerathne, 2018; Carrión-Mero,et.al, 2020). The research focuses on geo-tourism in the river basin area in Bandung Indonesia, or called Citarum River. The form of tourism based on the geological environment is geotourism as a new form of sustainable tourism that is more established and comprehensive, where more and more people visit geological sites (Dowling \& Newsome, 2017).

The elements of geotourism consist of connected components, all of which must be established for authentic geotourism to exist. There are three basic principles for geotourism: geology-based, sustainable and educational. These three characteristics are considered important so that a product can be considered as an example of geotourism (Dowling \& Newsome, 2017). The Citarum River area covers an area of approximately $12,000 \mathrm{~km} 2$ covering 13 Regency/City administrative areas in West Java Province, namely: Bandung Regency, West Bandung Regency, Bekasi Regency, Cianjur Regency, Bogor Regency, Indramayu Regency, Karawang Regency, Purwakarta Regency, Subang Regency, Sumedang Regency, Bandung City, Bekasi City and Cimahi City. Rivers, the number of large rivers in the Citarum River Basin is approximately 19 rivers that empties into the north sea or joins other rivers. The main river in the Citarum River Basin is the Citarum River. The Citarum River itself originates from Mount Wayang (Bandung Regency) and empties into Muara Gembong (Bekasi Regency). Based on Presidential Decree No. 12 of 2012 concerning River Basin, the Citarum River Basin consists of 19 watersheds. The Citarum river area play an important role as a source of water for the communities living there. Geo-heritage potential is found in several locations in the Citarum area, they are called geo-sites. Apart from natural (or primary) biodiversity, secondary biodiversity has the potential for geotourism and geo-education activities both outside and inside urban areas (Bajer, Kirchner \& Kubalíková, 2017).

Protection, education and sustainable development are promoted by geo-tourism where geoheritage is the main attraction. Tourists can enjoy geoheritage by traveling to the geosites. (Farsani, Coelho, \& Costa, 2010). Research on geo-diversity based on geo-tourism of Citarum River conducted to support conservation in the area and as a form of sustainable development, which will lead to the formulation of the problem, (1). What is the geodiversity in the Upper Citarum River? (2) What are the potential of geo-tourism and classification of the tourism area in the Upper Citarum River?

\section{Literature Review}

In 1999, publication of Geo-tourism was started in Indonesia by the Center for Geological Survey(Brahmantyo, 2013). Geo-tourism is a distinct subsector of natural area tourism, and not a form of tourism that include wider cultural and heritage components. The hierarchy of features in geotourism interest can be identified within a landscape (Dowling and Newsome, 2006). Geodiversity resources can be used for education and recreation in geotourism activities(Farsani, Coelho, Costa, \& Carvalho, 2011). Appreciation and learning about earth science, biodiversity conservation, and tourism promotion to geosites are part of geotourism, which is a form of natural tourism that focuses on geology and landscapes (Gerner, Rybar, Engel \& Domaracka, 2009).

Geotourism is a area of cognitive tourism and journey tourism based on visits to geological objects (geosites) and the creation of geological methods that are integrated with aesthetic stories received through contact with geosites (Hose \& Vasiljević, 2012). Geotourism targets to encourage tourism 
development possibilities, while ensuring the conservation and protecting geoheritage attributes (Dowling \& Newsome, 2013). The important of geotourism development is a knowledge of the identity or character of the area. To acquire this, geotourism is seen to be based totally on the concept that the surroundings includes abiotic, biotic, and cultural components (Dowling, 2013).

Tourism based on geological diversity and geo-history is a sector which is regarded from sustainable tourism with international growth and its formation is primarily based on 5 principal standards, 1) geology-based, 2) sustainable 3) educative as a characteristic, 4) useful for local people, and 5) creating geo-tourism satisfaction, (Dowling, 2011; Lazzari \& Aloia, 2014; Chlachula, 2019). In recent years, the interest of visitors nterest of site visitors in non-residing natural sources, such as geoheritage sites, has accelerated globally (Newsome, Dowling \& Leung, 2012). Geotourism areas also play an important role in driving the economy of local communities through the implementation of sustainable development (Dowling, 2013).

The correlation between sustainable development and geo-tourism, if it is well designed and managed, can provide economic, social and environmental advantages for geo-tourism destinations. Sustainable improvement as a media to create jobs, stimulating many geological assets through geotourism activities into the local economy and providing a whole community social welfare benefits (Olson \& Dowling, 2018). Geotourism development offers income, employment and skills development for local residents (Farsani, Coelho \& Costa, 2012).

Geoparks via tourism stimulate the advent of revolutionary local businesses such as small agencies, cottage industries and new jobs and generate a source of income (Farsani, Coelho \& Costa, 2010). Geotourism follows the principle of sustainability. Sustainability as a popular concept of tourism has three interrelated elements: environmental, socio-cultural and financial (Cottrell, Vaske, Shen, \& Ritter, 2007).

Geological diversity underlies and provides the most of identified ecosytem service type (Gray, 2011; Baron \& Gordon, 2013; Gray, Gordon, \& Brown, 2013, Herrera-Franco,et.al , 2021). Geodiversity is responsible for 25 major services classified to regulation, supporting, provision, cultural and knowledge services (Gray \& Gordon, 2020). The geodiversity is an attraction for geotourism and can be a recommended for tourist destinations, which are appropriate for tourists who valued natural landscape and outdoor activities.

\section{Methodology}

This research used a qualitative method to reveal and understand the potential of geo-tourism in the upper Citarum River, West Java, in order to gain an insight about geodiversity and geo-tourism in that area. Researchers collected and analyzed descriptively the data on field findings and presented the contained meaning descriptively.

The data collection method is carried out through observation and field surveys where primary and secondary data are obtained. The survey are carried out around the Upper Citarum River area. Secondary data collection methods are carried out through various spatial planning and tourism report at provincial and municipality level. In addition, other secondary data collected in the form of past research documents, tourism map in the area and topic. The geodiversity and selection of core areas, was asssessed using several criterias, which are accessibility, preservation, scientific worth and education significance (Solarska \& Zdzislaw, 2010; Bernat, 2014).

Anna and Zdzislaw (2010) and Sabzevari and Mirazizi (2014) use the fair and objective method, where each criterion has five items with appropriate weighting of points. The criteria are accessibility, preservation status of sites of scientific value and educational significance (Anifowose \& Kolawole, 2014). The value of each object being evaluated is shown in table 1 : 
Table 1 Rating scheme for the geoheritage resource value, description and evaluation

Range Interval Value Description and Evaluation

$25-30$

$0-8$
Outstanding

cords, special geological phenomena or landform features; Significant in occurrence or distribution, Having a special ecological function; or a combination of these

Rarely, in scientific records, special geological phenomena or landform features; Significant in occurrence or distribution, Having a special ecological function; or a combination of these.

Containing an important scientific records that are suitable for educational and research purposes.

Containing scientific notes which are useful for improving site knowledge and are suitable for research purposes.

Source: Modified by Rosana, et. al. (2016) and Law No. 26 of 2007 on spatial planning

Geo-tourism used the method above for identifying geo-site, Analysis of geosites and geotourism potential was conducted by using the descriptive analysis.

\section{Results and Discussion}

A geotourist destination has an attraction that can be offered to tourists. The attraction can be in the form of nature beauty the landscape, rich cultural heritage, or a sustainable environment. The nature resources of West Java that can be offered to tourists can be in the form of mountains, plantations, waterfalls, caves, and others. As for the wealth of cultural heritage, West Java can offer performances of angklung, wayang, and others. A sustainable environment can offer protected forests, or coral reef conservation, etc. The result found that upper Citarum River has 43 geodiversity, ranging from mountain, lake, crater, waterfall, hot spring to cliffs.

Most geodiversity are currently a tourist attraction in the area. The geo-tourism attraction in the upper Citarum River consist of geo-heritage, can become the main driving force of geo-tourists. Upper Citarum River has a potential to be developed as main geo-tourism destination with integrated geotrekking route. There are cultural and artificial tourist attractions nearby the upper Citarum geotourism destination. The number of tourist visiting these destinations mostly located in Bandung Regency is 1,274,026 people in 2020, 50\% less than in 2019 about 2,490,261 people (West Java Regency Statistics Agency 2021).

After listing the geodiversity, the researcher then assessed them based on several criteria. The summary value was obtained for each geodiversity which is then rated. The geodiversity assessed found that seven geo-diversity are categorized as outstanding geo-heritage. The outstanding geoheritage are: Cisanti Lake, Kawah Putih (Crater), Patuha Mountain, Cimanggu hot spring, Ranca Upas, Maribaya waterfall and Lava Selendang Dayang Sumbi/ Batik rock.

Situ Cisanti is located at an altitude of $\mathbf{1 5 0 0}$ meters above sea level and becomes the water source for the Citarum River. The process of the formation of Situ Cisanti was preceded by the existence of springs originating from Mount Wayang and Mount Windu. To accommodate these springs, a lake was created which is currently known as Lake or Situ Cisanti. Located in Tarumajaya Village, Kertasari District, Bandung District, Situ Cisanti has an area of about 5 ha and a depth of 3-4 m.

Kawah Putih is a crater formed from the last activity of Mount Patuha, which is located in Ciwidey, Bandung Regency, West Java. Initially, volcanic activity in this area began with the formation of Mount Patuha Tua, followed by the formation of Mount Patuha. This volcano has not erupted again since 1600 , but signs of this volcanic eruption can still be seen from the presence of solfatara and fumarola craters.

Mount Patuha is a mountain located in Rancabali, Ciwidey, Bandung Regency, West Java which has an altitude of 2,434 meters. Mount Patuha has a very exotic crater, namely a white crater. The crater, which was formed from the eruption of Mount Patuha, has a crater wall and white water. 
Cimanggu hot spring is located at an altitude of approximately 1,100 m above sea level in which there is a large expanse of tea plantations around it. In this tourist area, visitors can take a leisurely walk while enjoying the cool air and natural beauty around a tourist attraction that has a slope.

Ranca Upas is one of the campgrounds located on Ciwidey about $50 \mathrm{~km}$ from the center of Bandung City. It has an area of about 215 hectares, located at 1700 meters above sea level, and the area surrounded by a protected forest with a variety of flora.

Maribaya waterfall is still very natural with the surrounding nuances full of fresh green trees that will make anyone amazed by the serenity provided. Maribaya Waterfall is one of the several tourist objects in the Maribaya area, Lembang. Maribaya waterfall itself is part of the Forest Park Ir. H. Djuanda.

This geodiversity Batu Batik or known as Lava Pahoehoe and Selendang Dayang Sumbi Site was discovered in 2010. Geologically, this lava was formed based on the eruption of Mount Tangkuban Perahu Purba which flowed into the Cikapundung River.

Thus, these geodiversity explained above have a high score in value summary compared to other geodiversity in the list. They have high scientific worth and educational significance, hence they can be classified as outstanding geoheritage in the area. An important part of tourism offering and market is geoheritage, where tourists are increasingly picky in determining which geotourism places they want to see. (Božic \& Tomic, 2015). After listing and assessing the geodiversity, then the geo-site were classified into geo-tourism destination. The destination is based on its geo-heritage attraction is divided into three, primary destination, secondary destination and supporting destination.

Primary attractions are the main reason for tourists visiting while on vacation. The geoheritage with outstanding and high value became the main attraction. The secondary attractions are places visited by tourists while on a trip or while resting while on a long trip. Tourist attractions are provided for private or public use. The utilization of the potential tourist objects and attractions, started from natural, artificial, historical, artistic and cultural tourism must be carried out optimally, so that the surge in the number of tourist visits does not become a threat but gives a positive impact on economic progress and public welfare. Economically and environmentally sustainable, geoheritage sites contribute to their place in the tourism market(Božic \& Tomic, 2015).

Bandung Regency has 108 Cultural Sites which have been regulated by Law no. 11/2010 concerning Rules for Classifying Cultural Conservation. In addition, in this area there are also: Sindulang Waterfall, Kawah Putih, Hot Spring Water, Ranca Upas, Walini, Cibuni Crater, Patenggang Lake, Cisangkuy River, Cibolang Fot Spring Water, Pangalengan, Cilenca Lake. Bandung Regency is very rich in tourist areas, which can move the people's economy with great impact, not only to improve the regional economy but also the national economy.

Based on statistical data released by the BPS of West Java Province, in 2016 it was noted that Bandung Regency was the area most visited by domestic and foreign tourists, with 6,450,468 tourists. Of the many tourism objects in Bandung Regency, in the 2015-2017 fiscal year the tourism sector only contributed no more than $3 \%$ per year of its budget, where accommodation tax was the largest contributor among other aspects of income from the tourism sector income (Report of Original Regional Income Bandung Regency 2011-2017). Although, there are many tourism objects in Bandung Regency, but many of the land ownership for tourism objects is not owned by Bandung Regency, but by private companies and plantations that open tourism objects to be managed by themselves by involving the local community, so that their contribution to regional income is small.

Revenue from tourism objects is a source of revenue for tourism objects originating from entry ticket fees, parking fees and other income. Attractions that are still a favorite of tourists, are still dominated by tourism in the Lembang area such as the Tangkuban Parahu Mountain Nature Park, Maribaya. West Bandung Regency, regional income from the tourism sector in 2020 fall to 50 percent less than in 2019 which reached more than IDR 48.945 billion. According to data from the Tourism and Culture Office (Disparbud), in 2020 the PAD from the tourism sector was only around IDR 28.401 billion. (Pradana, 2021). 
Upper Citarum Zone is classified into primary, secondary and supporting geotourism destination, the primary purpose is the main reason for geotourist conduct their visits in the area. It has all the geotourism elements, process, form, and tourism in line with Newsome and Dowling's geotourism box. Primary geotourism destination includes Kawah Putih (crater), Kawah Kereta Api (crater), Curug Dago (waterfall), Curug Culang (waterfall), and Tebing Keraton (landscape).

Table 2 List Of Geodiversity Upper Citarum River

No Upper Citarum Area

$1 \quad$ Citarum Hulu

2

Citarik

$3 \quad$ Cikapundung

$4 \quad$ Cisangkuy

$5 \quad$ Ciwidey
Geodiversity

1) Cisanti lake, 2) Eti waterfall, 3) Malabar mountain, 4) Rakutak Mountain, 5)

Batu Nanceb site, 6)Kereta Api crater, 7) Manuk crater, 8) Hujan crater, 9)

Ciharus lake 10) Puncak Bintang 11) Curug Batu Templek 12) Palintang Cliff

10) Manglayang mountain, 11) Batu Kuda site, 12) Cinulang waterfall, 13)

Cilengkrang waterfall, 14) Kendan Mountain, 15) Mandalawangi mountain

16) Maribaya waterfall, 17) Omas waterfall, 18) Gunung Batu, 19) Cikapundung waterfall, 20) Dago waterfall, 21) Kidang waterfall, 22) Koleang waterfall, 23) Lalay waterfall, 24) Lava Selendang Dayang Sumbi/ Batu Batik, 25) Tebing Keraton, 26) Batu Templek waterfall

27) Puntang Mountain, 28) Cileunca lake, 29) Siliwangi waterfall, 30) Cibolang hot spring

31) Kawah Putih, 32) Patenggang lake, 33) Cimanggu hot spring, 34) Patuha mountain, 35) Cibuni crater, 36) Rengganis crater, 37) Cipanji crater, 38) Tilu Cipelah waterfall, 39) Careuh Mountain, 40) Tilu Ciwidey Mountain.

Source: Data 2020

Secondary destination can be developed into primary destination in the future. Yet, it must have the tourism elements in the area, including Mount Tilu Ciwidey, Puncak Bintang, Artapela national park, and Mount Kendan. The correlation between environment and development is fundamental problem. The lives of more than half the population are economically active in particular in the developing countries heavily depends on the environment. Supporting the primary destination is a cultural and artificial attractions that has links with elements of geotourism, for example of supporting tourism destination include the Geological Museum, the Siam King Inscription, Goa Goa, the Kampung Adat Cikondang, and the Dago Bengkok Hydroelectric Power Plant.

Table 3 Valorization result for geodiversity in upper Citarum river

\begin{tabular}{|c|c|c|c|c|c|c|c|}
\hline \multicolumn{2}{|c|}{ Geodiversity } & \multirow{2}{*}{$\begin{array}{c}\text { Access } \\
5\end{array}$} & \multirow{2}{*}{$\begin{array}{c}\begin{array}{c}\text { State of } \\
\text { Preservation }\end{array} \\
5\end{array}$} & \multirow{2}{*}{$\begin{array}{c}\text { Scientific } \\
\text { Worth } \\
10\end{array}$} & \multirow{2}{*}{$\begin{array}{c}\text { Education } \\
\text { Significance } \\
10\end{array}$} & \multirow{2}{*}{$\begin{array}{c}\text { Summarized } \\
\text { Value } \\
30\end{array}$} & \multirow{2}{*}{$\begin{array}{l}\text { Geoheritage } \\
\text { Outstanding }\end{array}$} \\
\hline 1. & Cisanti Lake & & & & & & \\
\hline $\begin{array}{l}2 . \\
\text { herita }\end{array}$ & $\begin{array}{l}\text { Batu Nanceb } \\
\text { ge }\end{array}$ & 5 & 4 & 6 & 8 & 23 & High \\
\hline $\begin{array}{l}3 . \\
\text { Mount }\end{array}$ & $\begin{array}{l}\text { Malabar } \\
\text { tain }\end{array}$ & 1 & 3 & 6 & 6 & 16 & Medium \\
\hline 4. & Ciharus Lake & 1 & 3 & 4 & 6 & 14 & Medium \\
\hline $\begin{array}{l}5 . \\
\text { Crater }\end{array}$ & Kereta Api & 3 & 4 & 8 & 8 & 23 & High \\
\hline 6. & Manuk Crater & 3 & 4 & 8 & 8 & 23 & High \\
\hline 7. & Hujan Cater & 3 & 4 & 8 & 8 & 23 & High \\
\hline 8. & Eti Waterfall & 1 & 4 & 6 & 8 & 19 & High \\
\hline 9. & Cileunca Lake & 4 & 4 & 8 & 6 & 22 & High \\
\hline 10. & Putih Crater & 5 & 5 & 8 & 8 & 26 & Outstanding \\
\hline
\end{tabular}




\section{Geodiversity}

11. Patuha

Mountain

12. Cimanggu hot spring

13. Ranca Upas

14. Patenggang

Lake

15. Cinulang

Waterfall

16. Batu Kuda Lake

17. Cilengkrang

Water

fall

18. Manglayang

mountain

19. Dago Waterfall

20. Batu Mountain

21. Maribaya

waterfall

22. Cikapundung

waterfall

23. Tebing Keraton

(Gorge)

24. Waterfall Omas

25. Lava

Selendang Dayang

Sumbi/ Batik rock

26. Lalay waterfall

27. Kidang waterfall

28. Koleang

waterfall

29. Cibuni

Rengganis Crater

30. Punceling Pass

31. Cipanji

Waterfall

32. Careuh

Mountain

33. Tilu Ciwidey Mountain

34. TWA Artapela

35. Siliwangi

Waterfall

36. Cibolang hot

spring

37. Rakutak

Mountain

\section{Access State of Scientific Education Summarized Preservation Worth Significance \\ Value}

5

8

10

Geoheritage

5

5

4

8

10

10

8

26

Outstanding

5

4

8

8

\section{6}

6

6

6

27

Outstanding

27

24

Outstanding

High

Medium

Medium

Medium

13

22

High

24

High

24

High

26

Outstanding

23

High

3

8

8

(3)

24

21

28

10

.

23

15

15

15

14

12

14

16

4

14

22

20
High

High

Outstanding

High

Medium

Medium

Medium

Medium

Medium

Medium

Medium

Low

Medium

High

High 


\begin{tabular}{lcccccc}
\multicolumn{1}{c}{ Geodiversity } & Access & $\begin{array}{c}\text { State of } \\
\text { Preservation }\end{array}$ & $\begin{array}{c}\text { Scientific } \\
\text { Worth }\end{array}$ & $\begin{array}{c}\text { Education } \\
\text { Significance }\end{array}$ & $\begin{array}{c}\text { Summarized } \\
\text { Value }\end{array}$ & Geoheritage \\
$\begin{array}{l}\text { 38. Mandalawangi } \\
\text { Mountain }\end{array}$ & 1 & 4 & 8 & 6 & 19 & High \\
$\begin{array}{l}\text { 39. Kendan } \\
\text { Mountain }\end{array}$ & 1 & 4 & 8 & 6 & 19 & High \\
$\begin{array}{l}\text { 40. Buru Masigit } \\
\text { Kareumbi Mountain }\end{array}$ & 3 & 4 & 8 & 4 & 19 & High \\
$\begin{array}{l}\text { 41. Curug Batu } \\
\text { Templek }\end{array}$ & 4 & 4 & 6 & 6 & 20 & Hedium \\
$\begin{array}{l}\text { 42. Puncak Bintang } \\
\text { 43. Tebing }\end{array}$ & 4 & 4 & 4 & 2 & 21 & High \\
$\begin{array}{l}\text { Palintang } \\
\text { Source: Research Data } 2020\end{array}$ & 4 & 5 & 6 & 6 & &
\end{tabular}

Table 4 Geotourism destination classification at the Citarum upper river

\begin{tabular}{|c|c|c|}
\hline $\begin{array}{l}\text { Main geotourism destination } \\
\text { Primer (A) }\end{array}$ & $\begin{array}{l}\text { Secondary tourism destination } \\
\text { (B) }\end{array}$ & $\begin{array}{l}\text { Supporting tourism destination } \\
\text { (C) }\end{array}$ \\
\hline 1. $\quad$ Cisanti Lake & 1. Cibuni Rengganis Crater & 1. Kertasari Tea Factory \\
\hline 2. Batu Nanceb heritage & Punceling Pass & Museum \\
\hline 3. Malabar Mountain & 3. Cipanji Waterfall & 2. Hulo Wetan Citarum site \\
\hline 4. Ciharus Lake & 4. Careuh Mountain & 3. Cikondang traditional vilage \\
\hline 5. Kereta Api Crater & 5. Tilu Ciwidey Mountain & $\begin{array}{l}\text { 4. Lebakmuncang tourism } \\
\text { village }\end{array}$ \\
\hline 6. Manuk Crater & 6. TWA Artapela & $5 \quad$ Ratu Alit Kabuvutan site \\
\hline 7. HujanCater & 7. Siliwangi Waterfall & 5. Batu Alit Kabuyutan site \\
\hline 8. Eti Waterfall & 8. Cibolang hot spring & 6. Jelekong tourism village \\
\hline 9. Cileunca Lake & 9. Rakutak Mountain & 7. Karanggantungan site \\
\hline 10. Putih Crater & 10. Mandalawangi Mountain & 8. Candi Bojong Emas site \\
\hline 11. Patuha Mountain & 11. Kendan Mountain & 9. Candi Bojong Menje \\
\hline 12. Cimanggu hot spring & 12. Buru Masigit Kareumbi & $\begin{array}{l}\text { 10. Archeology Museum } \\
\text { Bandung }\end{array}$ \\
\hline 13. Ranca Upas & Mountain & 11. Ciherang tourism village \\
\hline 14. Patenggang Lake & 13. Curug Batu Templek & 12. Kabuyutan Batu Lonceng site \\
\hline 15. Cinulang Waterfall & 14. Puncak Bintang & 13. Bosscha Observatory \\
\hline 16. Batu Kuda Lake & 15. Tebing Palintang & 14. Dutch Cave \\
\hline 17. Cilengkrang Water fall & & 15. Japanese cave \\
\hline 18. Manglayang mountain & & 16. Thai King heritage scripture \\
\hline 19. Dago Waterfall & & 17. Cikapundung BBWS \\
\hline 20. Batu Mountain & & 18. Museum Geology \\
\hline 21. Maribaya waterfall & & 19. Museum Sri Baduga \\
\hline 22. Cikapundung waterfall & & \\
\hline 23. Tebing Keraton (Gorge) & & \\
\hline 24. Waterfall Omas & & \\
\hline $\begin{array}{l}\text { 25. Lava Selendang Dayang } \\
\text { Sumbi/ Batik rock }\end{array}$ & & \\
\hline 26. Lalay waterfall & & \\
\hline 27. Kidang waterfall & & \\
\hline 28. Koleang waterfall & & \\
\hline
\end{tabular}

Source: Data 2020

Geo-tourism activities which can be done in the upper Citarum are exploring lush tropical forests (forest walk), watersport activities in rivers and lakes (swimming, tubing, kayaking or canoeing, rafting), mountain climbing, wildlife watching (bird watching), mountain biking (trail blazing activities), strolling 
along the botanical garden, heritage walk (monuments and heritage building), and doing charity or social activities (volunteerism, such as tree planting activities) in the local community.

Accessibility, including all transportation systems which consist of routes, terminals and vehicles. Amenities are facilities that are directly related to tourism such as accommodation (hotels, guesthouses), catering (restaurants, restaurants, food stalls, cafes), shops and other tourism services activities including all available activities in destinations and what activities visitors can do while they visit (Andini, Ardiyanto, Utami \& Wijaya, 2019). Components of a tourism product included attractions, amnesties and accessibility.

According to Swarbrooke and Horner (1996), an attraction is the most important component in the tourism system and becomes the main motivation for tourists to travel. The determining factors of tourist attraction are the desire, needs, perceptions and experiences of tourists. They also explained that attractions are one unit, a place that is very small and is limited by geographical area based on a main feature. The main destination is a larger area in which there are several attractions and other supporting facilities needed by tourists. Travelers visit to the area are able to create diverse opportunities for the community, one in every of which creates possibilities by optimizing the resources owned by enterprises. (Ribek \& Rihayana, 2019)

Geotourism areas can also be a powerful tool in managing geo-tourism resources in the region (Dowling \& Newsome, 2017). Geotourism helps tourists to take a leisurely stride and enjoy the local atmosphere. This means a proper consideration of a local communities as hosts to introduce culture, customs, lifestyle, traditional merchandise and socio-economic device to travelers. Tourism enhances the fabric life of local humans, with out inflicting the loss of conventional work systems and acculturation (Farsani, Coelho \& Costa, 2010).

Accommodation is closely related to tourism destination because it can add an attraction of tourism site. Service sectors such as accommodation and restaurants not only provide physical products such as lodging and food, but also create a pleasant atmosphere and a good impression of the products produced. Accomodation for geo-tourism can be found in Bandung and surrounding areas, ranging from local homestay to international hotel.

Accessibility of a destination influences vacation costs and the speed and pleasure of tourists in reaching a destination. Accessibility is not only an explanation of transportation equipment, but also other infrastructure such as roads, airports, railroads and ports, equipment (size and speed of public transportation), operational factors (operating routes, service frequency, and prices charged) and regulations government about transportation (Middleton, 1994, p. 87). Tourism is an activity of going to a place for pleasure with an aim of looking for entertainment, and without transportation, tourism will not exist. Transportation at destinations can be in the form of taxi, car rental buses, and bus stops for pedestrians. The managers of tourism companies would make higher and more effective decisions with minimum use of resources, by comprehending the connections amongst the important factors in development of tourism destination. (Ardani, Rahyuda, Giantari \& Sukaatmadja, 2019).

Tourism facilities are all types of facilities which are specifically shown to support the creation of facilities, comfort and safety of tourists in visiting tourist destinations. The facilities and tourism businesses in the upper Citarum River include accommodation, dining and drinking facilities, tourist travel facilities, and ornamental and recreational facilities. Geotourism facilities in the upper Citarum Zone in the form of the tourism industry, including accommodation, food, beverage, and tourist travel businesses.

Facilities for providing accommodation in the upper Citarum Zone include star and jasmine hotels, youth lodgings, tourist lodges and campsites. There are 540 accommodation service units which are available in the upper Citarum Zone. Food and drink provision facilities in the upper Citarum Zone are based on the West Java Disparbud classification of restaurants and cafes. The total number is 1,673 food and drink vendors are found.

Facilities for tourism in the upper Citarum Zone based on the West Java Disparbud are supported by travel agencies. In total there are 305 travel SMEs located across the Upper Citarum Area (West 
Java Tourism and Culture Statistics, 2018). Meanwhile, in the Cikapundung and Ciwidey area, the tourism activities have been a part of the livelihood of local communities. Many destinations are already well known to local toruists, this is indicated by the high tourist visits every weekend and long holidays.

Tourism public supporting facilities, in addition intended for the local community are also needed by tourists while in the destination area which includes financial, health, and worship facilities. Financial facilities in the upper Citarum Zone are classified based on a network of Government Banks, Private Banks, Regional Development Banks, and Foreign and Mixed Banks. Health facilities such as hospitals, health centers, and clinics have a role in facilitating the handling of tourists while in the destination.

There are 595 units health facilities which are located in the upper of Citarum River (West Java Tourism and Culture Statistics, 2018). Worshipping facilities in the Upper Citarum Zone are dominated by Islamic worship facilities with a total of 12,543 mosques and 11,770 prayer rooms. The availability of these worship facilities provides convenience for Muslim geo-tourists while they are in the upper Citarum Zone Destinations. Overall, the distribution of public facilities as supporting geo-tourism in the upper Citarum Zone is concentrated in Bandung Regency for tourism facilities and in the City of Bandung for financial and health facilities (West Java Tourism and Culture Statistics, 2018).

Generally, the upper of Citarum River as a geo-tourism destination has a good access in view of the availability of existing highway infrastructure, and also the readiness of public transportation in the area. There are some geo-sites which have a very good access, because the road towards the tourist gate and a public transport route to the location already exist. Transportation starts from Husein Sastranegara airport (regular scheduled international and domestic flights available), Bandros or Bandung Tourism On Bus is already available in several region (Diponegoro, City Hall, and Sabuga), taxis, and online transportation services are available in Bandung city and its vicinity. Overall, the Citarum river has a lot of potential to become a geo-tourism destination.

The attraction, amnesties and accessibilities support the upper Citarum area as geo-tourism destination. Thus, the development of the tourism industry in any region needs considering all kinds of aspects, it because the tourism industry is a service industry which cannot stand independently, they always have a correlation directly or even indirectly to various other sectors. It reflects the fact that the progress of the tourism industry not only relies on the tourism sector (Rawung, Salindeho, \& Mantiri, 2019). Geo-tourism encompasses rural tourism and sustains or even enhances the geological characteristics of an area (Farsani, Coelho \& Costa, 2012). Dowling dan Newsome (2006) argued that geotourism is sustainable tourism with a prime attention on geological features, which promotes environmental and cultural expertise, appreciation, and conservation.

\section{Conclusion}

The Upper Citarum has a potential geo-tourism resources with the presence of several geoheritage sites in the area, which can be an attraction for tourists. The distribution of geological diversity in the upper Citarum includes Citarik, Cisangkuy, Cikapundung, and Ciwidey. There are about 43 geodiversity and geo-sites which have been found and assessed. The geodiversity which have a potential to become main getourism attraction was evaluated.

Seven geodiversity and geosites have outstanding geoheritage value, which are: Cisanti Lake, Kawah Putih (Crater), Patuha Mountain, Cimanggu hot spring, Ranca Upas. The study classifies the Upper Citarum River into three categories, main tourism destination, secondary tourism destination and supporting tourism area. The development of upper Citarum River as geo-tourism destination based on geological diversity is supported by the availability of amenities, and accessibilities in the area.

From this study, the geo-trail can be developed for geotourism attraction of upper Citarum River and masterplan for geotourism in the area. Due to the limitation of this study, in future research on 
other areas of Citarum River can be implemented to have an overall picture of potential geo-tourism in Citarum River area.

\section{References}

1. Amir, A. F., Ghapar, A. A., Jamal, S. A., \& Ahmad, K. N. (2015). Sustainable tourism development: A study on community resilience for rural tourism in Malaysia. Procedia - Social and Behavioral Sciences, 168(6), 116-122. https://doi.org/10.1016/j.sbspro.2014.10.217

2. Andini, D., Ardiyanto, D., Utami, E., \& Wijaya, S. (2019, October). Geosite potential as tourism destination in Jebus West Bangka Regency Bangka Belitung Archipelago province. International Conference on Maritime and Archipelago (ICoMA 2018), 109-114. https://doi.org/10.2991/icoma18.2019.24.

3. Anifowose, Y. B. A., \& Kolawole, F. (2014). Appraisal of the geotourism potentials of the Idanre Hills, Nigeria. Geoheritage, 6(3), 193-203. https://doi.org/10.1007/s12371-014-0100-5

4. Anna, S., \& Zdzislaw. (2010). Geoheritage and geotourism potential of the Strzelin Hills (Sudetic Foreland, SW Poland). Geographica Pannonica, 14(4), 118-125.

https://doi.org/10.5937/GeoPan1004118S

5. Ardani, W., Rahyuda, K., Giantari, I. G. A. K., \& Sukaatmadja, I. P. G. (2019). Customer satisfaction and behavioral intentions in tourism: A literature review. International Journal of Applied Business and International Management, 4(3), 84-93. https://doi.org/10.32535/ijabim.v4i3.686

6. Arora, K., Rajput, S., \& Anand, R. R. (2020). Geomorphosites assessment for the development of scientific geo-tourism in North and Middle Andaman's, India. Geojournal of Tourism and Geosites, 32(4), 1244-1251. https://doi.org/10.30892/gtg.32408-564

7. Bajer, A., Kirchner, K., \& Kubalíková, L. (2017). Secondary geodiversity and its potential for urban geotourism: A case study from Brno city, Czech Republic. Quastiones Geographicae, 56(3), 63-73. https://doi.org/10.1515/quageo-2017-0024

8. Baron, H., \& Gordon, J. E. (2013). The role of geodiversity in delivering ecosystem services and benefits in Scotland. Scottish Journal of Geology, 49(1), 41-58. https://doi.org/10.1144/sjg2011-465

9. Bernat, S. (2014). Soundscapes and tourism-towards sustainable tourism. Problemy EkorozwojuProblems of Sustainable Development, 9(1), 107-117.

10.Božic, S., \& Tomic, N. (2015). Canyons and gorges as potential geotourism destinations in Serbia: Comparative analysis from two perspectives-general geotourists' and pure geotourists'. Open Geosciences, 7(1), 531-546. https://doi.org/10.1515/geo-2015-0040

11.Brahmantyo, B. (2013). Geotourism in Indonesian perspective. Proceedings of HAGI-IAGI Joint Convention, Medan.

12.Carrión-Mero, P. C., Morante-Carballo, F. E., Herrera-Franco, G. A., Maldonado-Zamora, A., \& PazSalas, N. (2020). The context of Ecuador's world heritage, for sustainable development strategies. International Journal of Design \& Nature and Ecodynamics, 15(1), 39-46.

https://doi.org/10.18280/ijdne.150106

13.Chlachula, J. (2019). Geo-tourism perspectives in East Kazakhstan. Geography, Environment, Sustainability, 12(2), 29-43. https://doi.org/10.24057/2071-9388-2018-78

14.Cottrell, S. P., Vaske, J. J., Shen, F., \& Ritter, P. (2007). Resident perceptions of sustainable tourism in Chongdugou, China. Society \& Natural Resources, 20(6), 512-513.

https://doi.org/10.1080/08941920701337986

15.Dowling, R. \& Newsome, D. (2006). Geotourism, sustainability, impacts and management. Oxford: Elsevier, Butterworth Heinemann.

16.Dowling, R. K. (2011). Geotourism's global growth. Geoheritage, 3(1), 1-13. https://doi.org/10.1007/s12371-010-0024-7 
17.Dowling, R. K. (2013). Global Geotourism - An emerging form of sustainable tourism. Czech Journal of Tourism, 2 (2), 59-79. https://doi.org/10.2478/cjot-2013-0004

18.Dowling, R. K., \& Newsome, D. (2017). Geotourism destinations - visitor impacts and site management considerations. Czech Journal of Tourism, 6(2), 111-129.

https://doi.org/10.1515/cjot-2017-0006

19.Farsani, N. T., Coelho, C., \& Costa, C. (2012). Geotourism and geoparks as gateways to socio-cultural sustainability in Qeshm Rural Areas, Iran. Asia Pacific Journal of Tourism Research, 17(1), 30-48. https://doi.org/10.1080/10941665.2011.610145

20.Farsani, N. T., Coelho, C., Costa, C., \& Carvalho, C. N. D (2011). Geoparks and geotourism: New approaches to sustainability for the 21 century. USA: Brown Walker Press.

21.Farsani, T. N., Coelho, C., \& Costa, C. (2010). Geoparks as art museums for geotourists. Journal of Tourism and Development, 2(13/14), 567-576.

22.Gerner, D., Rybar, P., Engel, J., \& Domaracka, L. (2009). Geotourizm marketing in Lake Constance region. Acta Montanistica Slovaca, 14(2), 197-204.

23.Gray, M. (2011). Other nature: Geodiversity and geosystem services. Environmental Conservation, 38(3), 271-74. https://doi.org/10.1017/S0376892911000117

24.Gray, M., \& Gordon, J. E. (2020). Geodiversity and the '8Gs': A response to Brocx \& Semeniuk (2019). Australian Journal of Earth Sciences, 67(3), 437-444. https://doi.org/10.1080/08120099.2020.1722965

25.Gray, M., Gordon, J. E., \& Brown, E. J. (2013). Geodiversity and the ecosystem approach: The contribution of geoscience in delivering integrated environmental management. Proceedings of the Geologists' Association, 124(4), 659-73. https://doi.org/10.1016/j.pgeola.2013.01.003

26.Herrera-Franco, G., Montalván-Burbano, N., Carrión-Mero, P., Jaya-Montalvo, M., \& GurumendiNoriega, M. (2021). Worldwide research on geoparks through bibliometric analysis. Sustainability, 13(3), 1175. https://doi.org/10.3390/su13031175

27.Hose, T. A. (1995). Selling the story of Britain's stone. Environmental Interpretation, 10(2), 16-17.

28. Hose, T. A., \& Vasiljević, D. A. (2012). Defining the nature and purpose of modern geotourism with particular reference to the United Kingdom and South-East Europe. Geoheritage, 4(1-2), 25-43. https://doi.org/10.1007/s12371-011-0050-0

29.Jamaluddin, Y. (2017, November). Innovation public goods management based on local culture-a case study of forest park management Ir. H. Djuanda, Indonesia. International Conference on Administrative Science (ICAS 2017), 232-236. https://doi.org/10.2991/icas-17.2017.55.

30.Law No. 26/2007 Indonesian spatial planning.

31.Lazzari, M., \& Aloia, A. (2014). Geoparks, geoheritage and geotourism: Opportunities and tools in sustainable development of the territory. Geojournal of Tourism and Geosites,13(1), 8-9.

32.Middleton, V. T. C. (1994). Marketing in travel and tourism. Oxford: Butterworth-Heinemann.

33.Mihic, S. D. \& Andrejevic, A. (2012). European policy for the promotion of inland waterway transport - A case study of the Danube River. In book Sustainable development - Policy and urban development - Tourism, Life Science, Management and Environment. Intechopen.

34.Newsome, D., Dowling, R., \& Leung Y-F. (2012). The nature and management of geotourism: A case study of two established iconic geotourism destinations. Tourism Management Perspectives, 2(3), 19-27. https://doi.org/10.1016/j.tmp.2011.12.009

35.Olson, K., \& Dowling, R. (2018). Geotourism and cultural heritage. Journal of Geoconservation Research, 1(1), 37-41. https://doi.org/10.30486/GCR.2018.540021

36.Pásková, M., Zelenka, J., Ogasawara, T., Zafala, B., \& Astete, I. (2021). The ABC concept-value added to the earth heritage interpretation? Geoheritage, 13(38), 1-25.

https://doi.org/10.1007/s12371-021-00558-8 
37.Pradana, W. (2021). Gegara COVID-19, PAD sektor wisata Bandung Barat merosot 50 persen. Retrieved from https://news.detik.com/berita-jawa-barat/d-5374309/gegara-covid-19-padsektor-wisata-bandung-barat-merosot-50-persen

38.Rawung, S. S., Salindeho, M. F. S., \& Mantiri, J. (2019). Analysis of the factors affecting tourist visits in Minahasa District. International Journal of Tourism and Hospitality in Asia Pasific, 2(3), 1-5. https://doi.org/10.32535/ijthap.v2i3.591

39.Ribek, P. K., \& Rihayana, I. G. (2019). Innovation as a strategy of agrowical competition advantage in improving marketing performance of luwak coffee products in Gianyar Bali. International Journal of Applied Business and International Management, 4(2), 41-48. https://doi.org/10.32535/ijabim.v4i2.565

40.Rosana, M. F., Yuningsih, T. E., Haryanto, I., Fauzielly, I., Zakaria, Z., Haryanto, A. D., \& Senjaya, Y. G. (2016). Study of geodiversity, geoheritage and conservation of the Ciletuh and Cisolok Regions, Sukabumi Regency, towards the establishment of a UNESCO global geopark. ALG final report. Padjadjaran University, Sumedang.

41.Sabzevari, A. A., \& Mirazizi, A. K. (2014). Assessing geo-tourism potential in local and sustainable development of tourism (A Case Study of Darband Sarab, Sahneh Town). Indian Journal Of Fundamental And Applied Life Sciences, 4(S4), 711-724.

42.Solarska, A., \& Jary, Z. (2010). Geoheritage and geotourism potential of the Strzelin Hills (Sudetic Foreland, SW Poland). Geographica Pannonica, 14(4), 118-125.

https://doi.org/10.5937/GeoPan1004118S

43.Sungkar, A., \& Brahmantyo, B. (2013). Eco-geotourism in Indonesia. In Ecotourism and sustainable tourism development in Indonesia: Potential, lessons and best practice, 162-206. Jakarta: Ministry of Tourism and Creative Economy.

44.Swarbrooke, J., \& Horner, S. (1996). Marketing tourism, hospitality, and leisure in Europe. Toronto: International Thomson Business Press.

45.West Java Tourism and Culture Statistics. (2018). Regarding health facilities located in the upper of Citarum River and Number of Tourists.

46. Wijerathne, K. B. P. C. (2018). Potential of Horton plains national park as geo tourism destination: Inventory \& Evaluation. The Journal of Social Sciences Research, 654-658. https://doi.org/10.32861/jssr.spi2.654.658

47.Zhang, J., Tian, M., Wu, F., \& Mei, X. (2013). Discussion on key points of geopark construction and development in China. Presented at the Third Asia Pacific Geoparks Network Symposium, For the Innovation of the APGN. Jeju Island, South Korea. 